\title{
Resistance of White-flowered Gourd to Sweetpotato Whitefly
}

\author{
A.N. Kishaba ${ }^{1}$ and S. Castle' \\ U.S. Department of Agriculture, Agricultural Research Service, Boyden \\ Entomology Laboratory, University of California, Riverside, CA 92521
}

\section{J.D. McCreight ${ }^{3}$ \\ U.S. Department of Agriculture, Agricultural Research Service, U.S. Agricultural Research Station, 1636 East Alisal Street, Salinas, CA 93905}

\author{
P.R. Desjardins ${ }^{4}$ \\ Department of Plant Pathology, University of California, Riverside, \\ CA 92521 \\ Additional index words. calabash gourd, bottle gourd, squash leaf curl virus, \\ pubescence, Cucurbitaceae, Lagenaria siceraria, Cucurbita lundelliana, Cucurbita \\ ecuadorensis, Cucumis melo, Bemisia tabaci
}

Abstract. Confined-leaf tests in a greenhouse showed Lagenaria siceraria (Molina) Standley plant introduction (PI) 442369 was as susceptible to sweetpotato whitefly, Bemisia tabaci Gennadius, oviposition as Cucumis melo L., Cucurbita ecuadorensis Cutler and Whitaker, and Cucurbita lundelliana Bailey, whereas L. siceraria accessions PI 419090, PI 419215, PI 432341, and PI 432342 were resistant. Resistance rankings of $L$. siceraria accessions based on adult counts in greenhouse and field tests were similar. Adult entrapment among trichomes was highest on adaxial leaf surfaces of $L$. siceraria PI 419090. Abaxial leaf trichome density was $48.7 / \mathrm{mm}^{2}$ on sweetpotato whitefly-resistant $L$. siceraria PI 432342, $42.1 / \mathrm{mm}^{2}$ on Cucurbita lundelliana PI 540895, and ranged from 51.0 to $85.5 / \mathrm{mm}^{2}$ on Cucurbita ecuadorensis PI 540896. Leaf trichome densities of selected plants of four $L$. siceraria accessions ranged from 33.0 to $52 / \mathrm{mm}^{2}$ on the abaxial and from 6.3 to $20.8 / \mathrm{mm}^{2}$ on the adaxial surface. Scanning electron micrographs of the abaxial leaf surface, the preferred surface for oviposition, suggest that trichome configuration (density and arrangement of different lengths) could be a factor in reduction of whitefly oviposition on $L$. siceraria.

Three whitefly species, including Bemisia tabaci the sweetpotato whitefly (SPWF), are sporadic pests of cotton (Gossypium hirsuturn L.) in Imperial Valley, Calif. (Gerling, 1967). In Fall 1981, the SPWF population reached an epidemic level (Butler et al., 1983). Cucurbits were severely damaged by SPWF feeding and infection with squash leaf curl (Flock and Mayhew, 1981) and lettuce infectious yellow viruses (Duffus et al., 1986). In 1990, a new biotype of the SPWF in Im-

Received for publication 25 Apr. 1992. Accepted for publication 28 May 1992. Research performed in cooperation with Univ. of California, Riverside. We thank J. Gonzales. J. Princioe. P. Sasaki, and J. Kitasako for their technical assistance. We thank T.J. Henneberry, D.S. Moreno, J.A. Webster, and D.A. Wolfenbarger for reviewing the manuscript. Mention of a proprietary product in this paper does not constitute endorsement of the product by the USDA. The cost of publishing this paper was defrayed in part by the payment of page charges. Under postal regulations, this paper therefore must be hereby marked advertisement solely to indicate this fact.

${ }^{1}$ Research Entomologist, retired. Present address: 1640 Sawpeck Way Paradise, CA 95969.

${ }^{2}$ Present address: Southwest Idaho Research and Extension Center, 29603 Univ. of Idaho Lane, Parma, ID 83660-9637.

${ }^{3}$ Research Horticulturist.

${ }^{4}$ Emeritus Professor of Plant Pathology.
Recently, we reported that none of four wild Cucurbita spp. cross-compatible with cultivated Cucurbita spp. were sufficiently resistant to squash leaf curl virus and SPWF$A$ and that the search for resistance should be continued (McCreight and Kishaba, 1991). In that same study, we reported that $11 \mathrm{~L}$. siceraria accessions were highly resistant to squash leaf curl. In an unpublished study, we found high resistance to SPWF-A in $L$. siceraria. We report here the differential response of selected Lagenaria accessions to SPWF-A. We describe the spatial arrangement of $L$. siceraria trichomes that might be important for resistance to SPWF-A and decrease the incidence of squash leaf curl virus infection. Response of these accessions to SPWF-B remains to be determined.

\section{Greenhouse studies}

Seven $L$. siceraria accessions were increased by controlled self-pollinations in a field plot for use in these studies; seed stocks were received from the Regional Plant Introduction Station, Experiment, Ga.; PI 419090 and PI 419215 from China; PI 432341 and PI 432342 from Cyprus; PI 438844, PI 438845, and PI 442369 from Mexico. Four L. siceraria accessions differing from PI 432341 for trichome configuration (length, arrangement, and density) were selected for study: PI 419090, PI 419215, PI 432342, PI 442369. Also included were Cucurbita ecuadorensis (PI 540893, Cucurbita lundelliana (PI 540896), and Cucumis melo (PI 414723). Lagenaria seeds only were scarified by excising a small portion of the seedcoat at the end of the seed opposite from the radicle. All seeds were planted in vermiculite; seedlings were transplanted into 1.5-liter plastic pots containing a mix of 1 peat : 4 soil : 5 sand : 5 silt : 5 vermiculite (by volume). Plants for leaf trichome counts were transferred into 3.6-liter containers and those for sleeve cage studies were transferred into 11-liter plastic pots. They were watered once daily with a nutrient solution (Ward, 1973), modified to contain 0.2 times the recommended minor element concentration. If necessary, a second watering was done with tepid tap water. perial Valley was found to cause silverleaf in squash (Cucurbia spp.) (Cohen et al., poinsettia, IV90, or B (SPWF-B) biotype, reached heretofore unseen levels in 1991 and caused much more damage through feeding than the previous biotype that has been designated the California, cotton, IV81, or A (SPWF-A) biotype (Cohen et al., 1992; Perring et al., 1992).
Table 1. Mean trichome density (per square millimeter) on three cucurbit species. In greenhouse, Riverside, Calif.

\begin{tabular}{|c|c|c|c|c|}
\hline Species, accession & $\begin{array}{c}\text { Leaf } \\
\text { dimension } \\
(\mathrm{cm})\end{array}$ & $\mathrm{n}^{\mathrm{y}}$ & Mean & $\mathrm{SE}$ \\
\hline \multicolumn{5}{|c|}{ Abaxial surface } \\
\hline Cucurbita lundelliana, PI 540896 & $10 \times 13$ & 13 & 42.1 & 0.52 \\
\hline Lagenaria siceraria, PI 432342 & $20 \times 23$ & 15 & 48.7 & 1.58 \\
\hline \multicolumn{5}{|l|}{ Cucurbita ecuadorensis, PI 540895} \\
\hline Plant no. 3 & $15 \times 19$ & 30 & 51.0 & 0.88 \\
\hline Plant no. 4 & $10 \times 14-14 \times 18$ & 75 & 79.8 & 1.35 \\
\hline Plant no. 5 & $13 \times 18-18 \times 25$ & 80 & 85.6 & 1.14 \\
\hline Plant no. 6 & $13 \times 18-17 \times 22$ & 60 & 75.6 & 0.70 \\
\hline \multicolumn{5}{|c|}{ Adaxial surface } \\
\hline C. lundelliana, PI 540896 & $10 \times 13$ & 9 & 16.6 & 1.11 \\
\hline L. siceraria, PI 432342 & $20 \times 23$ & 15 & 20.0 & 1.28 \\
\hline C. ecuadorensis, PI 540895 & $15 \times 19$ & 30 & 3.9 & 0.10 \\
\hline
\end{tabular}

${ }^{\mathrm{z}}$ Length $\times$ width.

${ }^{\mathrm{y}}$ Number of $2-\mathrm{mm}^{2}$ areas sampled. 

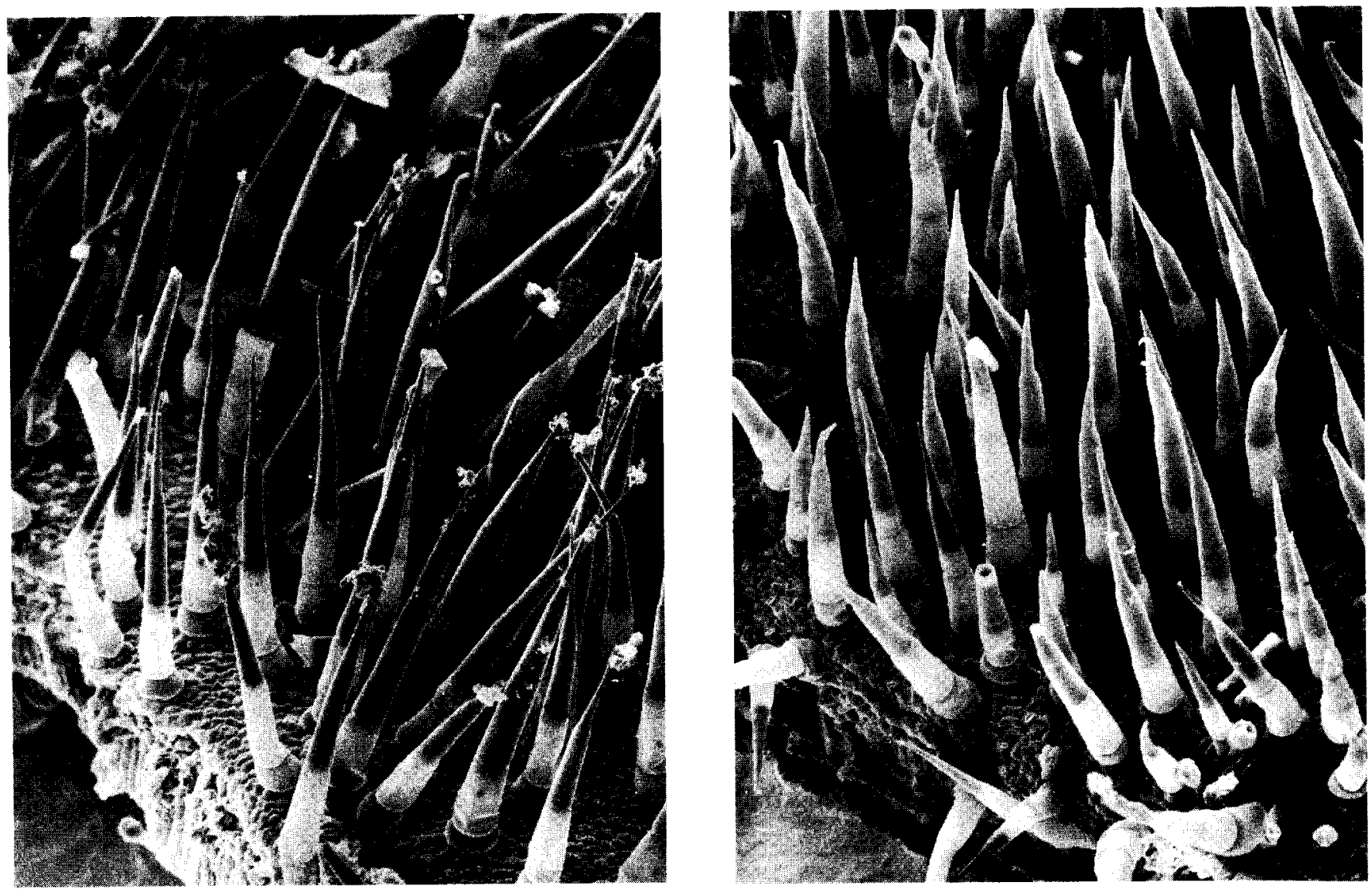

Fig. 1. Abaxial trichomes on Lagenaria siceraria PI 432342 (left) and PI 442369 (right). Scanning electron micrograph, $\times 123,55^{\circ}$ tilt.

Table 2. Trichome density (per square millimeter) on the two leaf surfaces of Lagenatia siceraria. In greenhouse, Riverside, Calif.

\begin{tabular}{|c|c|c|c|c|c|c|c|c|}
\hline \multirow[b]{2}{*}{ PI } & \multirow{2}{*}{$\begin{array}{c}\text { Plant } \\
\text { no. }\end{array}$} & \multirow{2}{*}{$\begin{array}{c}\text { Leaf } \\
\text { dimensions }{ }^{2} \\
(\mathrm{~cm})\end{array}$} & \multicolumn{3}{|c|}{ Abaxial } & \multicolumn{3}{|c|}{ Adaxial } \\
\hline & & & $n^{y}$ & Mean & SE & $\mathrm{n}^{\mathrm{y}}$ & Mean & SE \\
\hline 419090 & 1 & $20 \times 29$ & 30 & 43.6 & 0.44 & 30 & 20.8 & 0.33 \\
\hline \multirow[t]{2}{*}{419215} & 1 & $16 \times 21$ & 14 & 41.3 & 0.97 & 16 & 15.4 & 0.85 \\
\hline & 2 & $18 \times 28$ & 10 & 33.0 & 1.61 & & & \\
\hline 432341 & 1 & $17 \times 22$ & 10 & 50.1 & 2.29 & 9 & 12.8 & 0.89 \\
\hline \multirow[t]{7}{*}{432342} & 1 & $18 \times 24$ & 15 & 36.7 & 0.82 & 15 & 14.8 & 1.06 \\
\hline & 2 & $23 \times 29$ & 15 & 47.9 & 0.68 & 15 & 13.3 & 0.58 \\
\hline & 3 & $20 \times 30$ & 15 & 38.2 & 1.01 & 15 & 11.8 & 0.53 \\
\hline & 4 & $18 \times 24$ & 15 & 52.0 & 1.03 & 15 & 14.5 & 0.54 \\
\hline & 5 & $18 \times 24$ & 15 & 48.1 & 1.18 & & & \\
\hline & 6 & $21 \times 27$ & 15 & 35.7 & 0.48 & 15 & 15.5 & 0.80 \\
\hline & 7 & $20 \times 27$ & 15 & 49.8 & 0.89 & 15 & 15.6 & 0.81 \\
\hline \multirow[t]{2}{*}{442369} & 1 & $24 \times 32$ & 30 & 41.2 & 0.84 & 30 & 6.3 & 0.20 \\
\hline & 2 & $22 \times 32$ & 30 & 38.9 & 0.63 & 30 & 7.6 & 0.63 \\
\hline
\end{tabular}

${ }^{\mathrm{z}}$ Length $\times$ width.

${ }^{\mathrm{y}}$ Number of $2-\mathrm{mm}^{2}$ areas sampled.

Trichome counts. Leaves were considered mature when two to four basal leaves were of nearly equal size. Trichome density of these leaves (one leaf per plant, one to seven plants of each PI) was measured by laying a 2- $\mathrm{mm}^{2}$ template over the abaxial and adaxial surfaces of the leaves and counting the trichomes within the perimeter. The area was lightly dusted with talc to reduce glare and make the trichomes more visible. Counts were made with the aid of a dissecting scope at $\times 40$. Equal numbers of samples were taken near the midrib, equidistant between midrib and leaf margin, and near the leaf margin. Blade lengths and widths of the leaves sam- pled were also measured. Counts were combined by plant for calculation of means and SE; $t$ tests $(P=0.05)$ were calculated for comparing any two means.

Feeding and oviposition studies. Sleeve cages were used to confine 25 SPWF-A pairs to a single, whole, attached leaf of each PI in a randomized complete-block design with three blocks. The sleeve cages $(\approx 28$ liters $)$ were formed with two $30.5-\mathrm{cm}^{2}$ aluminum screen frames spaced $30.5 \mathrm{~cm}$ apart. The center four surfaces were clear Mylar film wrapped around the frame and held in place with duct tape. Both frame ends were covered with loose-fitting surgical stocking ma- terial that provided an insect-proof seal when secured around the stem.

In the first test, flies on each surface of the leaf were counted daily for 3 days. After 5 days of oviposition, plants were fumigated with Vapona Florafog (E.C. Geiger Co., Harleysville, Pa.), and eggs on each surface were counted and recorded separately. A second test was done using different sets of three plants of each plant accession. The procedure was similar in the second test, with the exception that counts of the flies were made twice daily for 3 days. Adult counts on the three leaves were summed each time and considered as replicates in time for analysis of variance (ANOVA) using MSTAT (Michigan State Univ.). For the data on eggs, counts on each leaf (plant) were considered a replicate.

\section{Field study}

Six L. sicerartia accessions (PI 419215, PI 419090, PI 432341, PI 432342, PI 438844, PI 442369), three Cucurbita lundelliana $\mathrm{S}_{1}$ selections for high trichome density from PI 540897 and PI 540898, and six Cucumis melo accessions (PI 414723, PMR Honeydew, WMR 29, AR 5, 'Top Mark', and 'PMR 45') were planted 10 Aug. 1987 in a field at the U.S. Dept. of Agriculture-Agricultural Research Service, Irrigated Desert Research Station, Brawley, Calif., in a randomized complete block with five replications. Each replication consisted of 15 contiguous plots on 2.3-m centers, and each plot consisted of three two-plant hills spaced $2.1 \mathrm{~m}$ apart. 
Table 3. Mean sweetpotato whitefly adult and egg counts on adaxial and abaxial leaf surfaces of whole attached leaves confined in Mylar-covered-sleeve cages. In greenhouse, Riverside, Calif. ${ }^{2}$

\begin{tabular}{|c|c|c|c|c|c|c|c|c|}
\hline \multirow[b]{3}{*}{ Entry, accession } & \multicolumn{4}{|c|}{ Adults } & \multicolumn{4}{|c|}{ Eggs } \\
\hline & \multicolumn{2}{|c|}{ Abaxial } & \multicolumn{2}{|c|}{ Adaxial } & \multicolumn{2}{|c|}{ Abaxial } & \multicolumn{2}{|c|}{ Adaxial } \\
\hline & First ${ }^{y}$ & Second & First & Second & First ${ }^{x}$ & Second & First $^{x}$ & Second $\mathrm{d}^{\mathbf{x}}$ \\
\hline \multicolumn{9}{|l|}{ Lagenaria siceraria } \\
\hline Pl 419090 & $7 \mathrm{c}$ & $6 \mathrm{c}$ & $44 a^{w}$ & $32 a$ & 14 & $39 \mathrm{~b}$ & 96 & 108 \\
\hline PI 419215 & $15 \mathrm{c}$ & $9 \mathrm{c}$ & $19 \mathrm{bc}$ & $23 \mathrm{~b}$ & 67 & $20 \mathrm{~b}$ & 93 & 109 \\
\hline PI 432341 & $18 \mathrm{c}$ & $6 \mathrm{c}$ & $23 \mathrm{~b}$ & $19 \mathrm{~b}$ & 35 & $15 \mathrm{~b}$ & 182 & 111 \\
\hline PI432342 & $4 c$ & $6 \mathrm{c}$ & $25 \mathrm{~b}$ & $22 \mathrm{~b}$ & 5 & $35 \mathrm{~b}$ & 87 & 174 \\
\hline PI 442369 & $54 \mathrm{~b}$ & $56 \mathrm{~b}$ & $3 c$ & $4 c$ & 421 & 511 a & 119 & 122 \\
\hline Cucurbita ecuadorensis, & & & & & & & & \\
\hline PI 540895 & $56 \mathrm{~b}$ & $87 \mathrm{a}$ & $1 \mathrm{c}$ & $3 c$ & 373 & $490 \mathrm{a}$ & 48 & 90 \\
\hline $\begin{array}{l}\text { Cucurbita lundelliana, } \\
\text { PI } 540896\end{array}$ & $69 \mathrm{a}$ & $66 \mathrm{~b}$ & $2 c$ & $4 \mathrm{c}$ & 430 & $480 \mathrm{a}$ & 8 & 35 \\
\hline $\begin{array}{l}\text { Cucumis melo, } \\
\text { PI } 414723\end{array}$ & $54 \mathrm{~b}$ & $61 \mathrm{~b}$ & $2 c$ & $3 \mathrm{c}$ & 217 & 344 a & 48 & 78 \\
\hline
\end{tabular}

${ }^{z}$ Twenty-five swectpotato whitefly pairs introduced into cages at start of each of two tests.

yFirst and second tests.

x Large variation accounts for lack of significant differences.

wean separation within columns at $P=0.05$, Student-Newman-Keul's test.

Table 4. Mean adult whitefly counts on the two leaf surfaces and plant condition of selected cucurbits. In field, Brawlcy, Calif.

\begin{tabular}{|c|c|c|c|}
\hline Entry & Abaxial & Adaxial & $\begin{array}{c}\text { Plant }^{2} \\
\text { condition } \\
\end{array}$ \\
\hline \multicolumn{4}{|l|}{ Cucumis melo } \\
\hline PI 414723 & $230 c^{y}$ & $3.6 \mathrm{~b}^{\mathrm{y}}$ & $1.90 \mathrm{~d}^{\mathrm{y}}$ \\
\hline PMR Honeydew & $228 \mathrm{c}$ & $1.8 \mathrm{~b}$ & $1.60 \mathrm{~d}$ \\
\hline WMR 29 & $114 \mathrm{~d}$ & $1.6 \mathrm{~b}$ & $1.08 \mathrm{~d}$ \\
\hline AR 5 & $197 \mathrm{~cd}$ & $1.2 \mathrm{~b}$ & $1.30 \mathrm{~d}$ \\
\hline Topmark & $191 \mathrm{~cd}$ & $1.8 \mathrm{~b}$ & $1.20 \mathrm{~d}$ \\
\hline PMR 45 & $159 \mathrm{~cd}$ & $1.8 \mathrm{~b}$ & $1.20 \mathrm{~d}$ \\
\hline \multicolumn{4}{|c|}{ Cucurbita lundelliana } \\
\hline PI $540898\left(S_{1}\right)$ & $753 \mathrm{a}$ & $4.25 b$ & $4.64 \mathrm{~b}$ \\
\hline PI $540897\left(S_{1}\right)$ & $560 \mathrm{~b}$ & $4.00 \mathrm{~b}$ & $5.06 \mathrm{~b}$ \\
\hline \multicolumn{4}{|l|}{ Lagenaria siceraria } \\
\hline PI 419090 & $44 \mathrm{e}$ & $262.00 a$ & $6.80 \mathrm{a}$ \\
\hline PI 419215 & $57 \mathrm{e}$ & $14.60 \mathrm{~b}$ & $7.20 \mathrm{a}$ \\
\hline PI 432341 & 33 e & $4.25 \mathrm{~b}$ & $7.00 \mathrm{a}$ \\
\hline PI 432342 & $21 \mathrm{e}$ & $16.60 \mathrm{~b}$ & $7.00 \mathrm{a}$ \\
\hline PI 438844 & $124 \mathrm{~d}$ & $4.00 \mathrm{~b}$ & $5.06 \mathrm{~b}$ \\
\hline PI 442369 & $180 \mathrm{~cd}$ & $4.25 \mathrm{~b}$ & $3.60 \mathrm{c}$ \\
\hline
\end{tabular}

${ }^{\mathrm{z}}$ Plant condition rating scale: $1=$ plant dead; 2 to $3=$ severely stunted but still alive; 4 to $6=$ yellow and mildly stunted; 7 to $9=$ mild yellow and vigorous.

${ }^{\mathrm{y}}$ Mean separation within column at $P=0.05$, Student-Newman-Keul's test.

Replications were separated by $4.9-\mathrm{m}$ barren buffers. Adult SPWF-A were counted on 10 and 22 Sept. (31 and 43 days postplanting). For the first count, adult SPWF-A were counted on half of the adaxial and abaxial surfaces of 10 leaves per plot; counts from each plant were kept separate. This procedure was cumbersome, and the data (not shown) were highly variable. Following the recommendation of Edelson (1986) for sampling insects in Cucumis melo, we increased the number of unit areas sampled to 10 per leaf and decreased the size of the unit area per sample to $1.21 \mathrm{~cm}^{2}$ by use of a grid overlaid a short distance above the leaf surface so as not to disturb the flies; 10 sample counts were taken from two intermediate leaves selected at random.

Plant condition was evaluated on a plot basis on 28 Oct. (79 days postplanting) as follows: $1=$ plants dead; 2 to $3=$ plants extremely stunted and yellow crown leaves; 4 to $6=$ plants intermediate in growth with yellow crown leaves; and 7 to $9=$ very slight yellowing of crown leaves and vines quite vigorous. Data were converted to $\sqrt{\mathrm{x}}$ or $\sqrt{\mathrm{x}+0.5}$ as appropriate. Missing data (five plots) were calculated before ANOVA (Snedecor, 1956), and the SE was adjusted accordingly before means separation by use of the Student-Newman-Keul's test using the range module in MSTAT.

\section{Scanning electron micrograph studies}

Mature leaf samples were taken from $L$. siceraria accessions PI 419090, PI 432341, PI 432342, PI 438844, and PI 442369. Young leaf samples were also taken from PI 419090. All leaf samples were obtained from the field plot at Brawley. With the aid of a dissecting stereo microscope, leaf disks were cut from the undamaged midleaf area (at midblade length and equidistant between the midrib and the leaf margin) using a 5-mm cork borer. General techniques described by Hayat (1978) were followed to prepare the leaf disks for scanning electron micrographs. Specifically, disks were fixed in $2.5 \%$ glutaraldehyde solution in $0.15 \mathrm{M} \mathrm{NaPO}_{4}$ buffer, $\mathrm{pH}$ 7.3. Penetration of the fixing solution into the disks was facilitated by placing the vials on ice in a vacuum desiccator until the disks sank in the vials. Disks were then washed in $0.15 \mathrm{M}$ $\mathrm{NaPO}_{4}$ buffer, $\mathrm{pH} 7.3$, using four changes of buffer over $1 \mathrm{~h}$. Disks were postfixed in $1 \%$ osmic acid in $0.15 \mathrm{M} \mathrm{NaPO}_{4}$ buffer, $\mathrm{pH}$ 7.3 , for $1 \mathrm{~h}$ at ice-bath temperature and then rinsed in the washing buffer with four changes over $50 \mathrm{~min}$. Dehydration was initiated in $30 \%$ ethanol at room temperature with two ethanol changes over $30 \mathrm{~min}$, followed by two changes in $50 \%$ ethanol over $90 \mathrm{~min}$ at room temperature. While still in 50\% ethanol, the disks were placed in a cold room at icebath temperature overnight. The following day, they were brought to room temperature and given two rinses in $70 \%$ and $95 \%$ ethanol each at 30-min intervals. Disks were then transferred through four changes of absolute ethanol at room temperature at 30 -min intervals.

The disks were then placed in a drier (Tousinis Autosamdri-810 critical point; Tousinis Research, Rockville, Md.). Dried disks were subsequently attached to scanning electron microscope (SEM) stubs with silver paint either by abaxial or adaxial leaf surfaces. The stubs with attached disks were stored temporarily in a vacuum desiccator containing Drierite (Fischer Scientific, Tustin, Calif.) desiccant. Some of the stubs were coated with gold in a sputter-coater (Technics Hummer V; Technics, Alexandria, Va.), while others were rotary shadow cast with gold in an Edwards vacuum evaporator (Edwards High Vacuum, El Segundo, Calif.) at an angle of $38^{\circ}$ to $40^{\circ}$ to the center of the stubs. Disks were examined and photographed at several magnifications and various tilt angles in the SEM (Model Jeol JSM35C; Jeol USA, Peabody, Mass.).

Trichome lengths were measured from photographs taken at $30^{\circ}, 55^{\circ}$, or $60^{\circ}$ tilt angle and $\times 78, \times 180$, or $\times 200$ magnification. Means and SD were calculated and compared with PI 432342 using paired $t$ tests $(P=0.05)$.

Mean abaxial trichome density was lowest on Cucurbita lundelliana, intermediate on $L$. siceraria, and about twice as dense on $\mathrm{Cu}$ curbita ecuadorensis plant no. 5 (Table 1). On the adaxial surface, the lowest density was on Cucurbita ecuadorensis, intermediate on Cucurbita lundelliana, and highest on L. siceraria, but which was less than half of the density on the abaxial side.

Leaf trichome density varied among and within $L$. sicaria accessions (Table 2). On the abaxial surface, the lowest density was on PI 419215; the highest was on plant no. 4 of PI 432342. Leaf trichome counts of leaves from seven plants of PI 432342 ranged from 
Table 5. Mean leaf hair length $(\mu \mathrm{m})$ of selected Lagenaria siceraria PIs from scanning electron micrographs taken at various tilts and magnifications. In field, Brawley, Calif.

\begin{tabular}{|c|c|c|c|c|c|c|c|c|c|}
\hline \multirow[b]{2}{*}{$\underline{\text { PI }}$} & \multirow{2}{*}{$\begin{array}{l}\text { No. hairs } \\
\text { measured }\end{array}$} & \multirow[b]{2}{*}{ Mean \pm SE } & \multirow[b]{2}{*}{ Range } & \multicolumn{6}{|c|}{ Frequency distribution ${ }^{2}$} \\
\hline & & & & -3 & -2 & -1 & +1 & +2 & +3 \\
\hline \multicolumn{10}{|c|}{$30^{\circ}$ Tilt and $\times 200$} \\
\hline 432342 & 9 & $333 \pm 27.2$ & $218-482$ & 0 & 2 & 4 & 1 & 2 & 0 \\
\hline 438844 & 12 & $190 \pm 18.5$ & $124-335$ & 8 & 3 & 0 & 1 & 0 & 0 \\
\hline 432341 & 8 & $212 \pm 33.9$ & $94-382$ & 2 & 3 & 2 & 1 & 0 & 0 \\
\hline 442369 & 12 & $195 \pm 12.8$ & $129-288$ & 11 & 1 & 0 & 0 & 0 & 0 \\
\hline \multicolumn{10}{|c|}{$55^{\circ}$ Tilt and $\times 78$} \\
\hline \multicolumn{10}{|l|}{ Set 1} \\
\hline 432342 & 15 & $429 \pm 22.0$ & $286-571$ & 1 & 3 & 4 & 5 & 2 & 0 \\
\hline 442369 & 15 & $246 \pm 12.9$ & $143-314$ & 15 & 0 & 0 & 0 & 0 & 0 \\
\hline \multicolumn{10}{|l|}{ Set 2} \\
\hline 432342 & 15 & $431 \pm 21.2$ & $283-600$ & 0 & 2 & 5 & 7 & 0 & 1 \\
\hline 442369 & 15 & $229 \pm 15.2$ & $167-367$ & 13 & 2 & 0 & 0 & 0 & 0 \\
\hline \multicolumn{10}{|c|}{$60^{\circ}$ Tilt and $\times 180$} \\
\hline $\begin{array}{l}432342 \\
442369^{y}\end{array}$ & 10 & $359 \pm 20.2$ & $247-424$ & 0 & 1 & 4 & 3 & 2 & 0 \\
\hline No. 1 & 10 & $285 \pm 21.0$ & $188-394$ & 3 & 2 & 4 & 1 & 0 & 0 \\
\hline No. 2 & 10 & $279 \pm 18.1$ & $218-394$ & 4 & 3 & 2 & 1 & 0 & 0 \\
\hline No. 3 & 10 & $248 \pm 20.3$ & $165-329$ & 5 & 1 & 4 & 0 & 0 & 0 \\
\hline
\end{tabular}

${ }^{\mathrm{z}}$ Number of trichomes grouped in categories \pm respective SD.

${ }^{\mathrm{y}}$ Scanning electron micrograph taken at $\times 200$ and measurements adjusted to $\times 180$ for comparison.

35.7 to $52.0 / \mathrm{mm}^{2}$ and covered the full range found among the other Lagenaria $\mathrm{Pk}$. The highest adaxial trichome density was on PI 419090; the lowest was on PI 442369 (Table 2).

In sleeve cages, more adults were on abaxial than adaxial surfaces of Cucurbita ecuadorensis, Cucurbita lundelliana, Cucumis melo, and L. siceraria PI 442369 (Table 3). On $L$. siceraria accessions PI 419090 and PI 432342, more adults were found on the adaxial leaf surface. Whiteflies were nearly equally distributed on the two surfaces of $L$. siceraria accessions PI 419215 and PI 432341. No effort was made to determine whether these flies were simply resting or entangled among the trichomes, because accurate observation would have required magnification and would have disturbed the insects.

Egg counts on the abaxial surface of all entries tested here followed the same pattern as the abaxial adult counts (Table 3). This was true also for the adaxial surfaces of $\mathrm{Cu}$ curbita ecuadorensis, Cucurbita lundelliana, and Cucumis melo but not for the five L. siceraria PIs. PI 442369 had only three adults on the adaxial surface but had the second highest adaxial egg count (119 clumped in a small area). PI 419090 had the highest adaxial adult count (44) but had only 96 eggs (intermediate) on the adaxial surface (Table 3). This distribution may have been due to flies on the adaxial surface of PI 419090 being immobilized among the leaf trichomes. Adaxial egg counts on L. siceraria PI 442369 were similar to those on Cucurbita ecuadorensis, Cucurbita lundelliana, and Cucumis melo, but its abaxial egg counts were similar to those on the other four $L$. siceraria PIs.

Combined across species and tests, the coefficient of correlation of trichome density and oviposition on the abaxial surface was 0.312 . That value is probably because $\mathrm{Cu}$ curbita ecuadorensis had one of the highest egg counts and also the highest trichome density, while L. siceraria PI 432342 trichome count was 0.5 times as high, but the egg count was 0.0125 times as high. For comparison within $L$. siceraria, the trichome density on PI 442369 was the same as on PI 432342 , but the egg counts were 15 to 84 times higher and about the same as on $\mathrm{Cu}$ curbita lundelliana, Cucurbita ecuadorensis, and Cucumis melo. In addition, Cucumis melo PI 414723 (excluded from correlation analysis) had a very low trichome density (data not presented) but a high egg count. Thus, it appears that trichome density within the range observed in these studies did not affect oviposition.

In the field, abaxial whitefly counts on the two Cucurbita lundelliana inbreds were the highest, with adult counts of 753 and 560 compared with a low of 21 on $L$. siceraria PI 432342 (Table 4). Adult counts on L. siceraria PI 442369 and PI 438844 were intermediate along with all of the Cucumis melo lines. Whitefly counts were the lowest on $L$. siceraria PI 419215, PI 419090, PI 432341, and PI 432342. On the adaxial surface, the highest count was on PI 419090, 262 flies. Thus, also in the field it appears that resistance did not directly vary with hair density.

Mean trichome lengths on $L$. siceraria PI 432342 ranged from 359 to $429 \mu \mathrm{m}$ (Table $5)$; mean lengths on the other three $L$. siceraria accessions were significantly shorter $(P$ $=0.05)$. Mean trichome length on PI 432141 is probably greater than indicated by its mean; many were broken in the SEM. Frequency distributions of the trichome lengths emphasize the differences of PI 432342 from PI 438844 and PI 442369 (Table 5). PI 438844 and 442369 had significantly higher abaxial egg counts than PI 432342 (Table 3). Figure 1 shows the trichome distributions on PI 432342 and 442369.

The six Cucumis melo entries were nearly dead; L. siceraria PI 442369 was only slightly better. Cucurbita lundelliana and L. sicer- aria PI 438844 were rated intermediate for plant condition, while the four other $L$. siceraria accessions were vigorously growing with only minor yellowing of the crown leaves (Table 4).

Turnipseed (1977) found no consistent response alteration of the bandedwinged whitefly [Trialeurodes abutilonea (Haldeman)] with trichome length variation in soybean [Glycine $\max$ (L.) Merr]. But the trichome density was much less: $14 / \mathrm{mm}^{2}$ $(\approx 0.25$ to 0.33 times that on susceptible $\mathrm{Cu}$ curbita lundelliana). Hoxie et al. (1975) and Webster et al. (1975) showed that with wheat (Triticum aestivum L.), resistance to cereal leaf beetle (Oulema melanoplus L.) feeding depends on trichome density and length. This situation could also be true for $L$. siceraria: trichomes on the resistant PI 432342 were significantly longer than those of the susceptible PI 442369.

The potential role of trichome arrangement and length in sweetpotato whitefly resistance does not necessarily negate the earlier work on cotton by Butler and Henneberry (1984), which showed that sweetpotato whitefly preferred pubescent rather than glabrous leaves. Interactions of whitefly behavior, host-plant, and host-plant microenvironment are also at play. Cotton is upright, and $L$. siceraria is prostrate. For the latter species, only the abaxial surface would provide shelter for the sweetpotato whiteflies in the hot summer. Sippel et al. (1987) discussed the possibility of differential parasitism between glabrous and hirsute cotton because the oak leaf and glabrous characters accounted for only $60 \%$ of the variation.

All of the hosts tested herein are pubescent. Resistance appears to depend on the spatial arrangement of trichomes of different lengths. Stout, medium to long trichomes interspersed among dense, short trichomes (like those of PI 442369, Fig. 1) appear to reduce oviposition on L. sicerartia PI 432342. Pubescence seems to be the ovipositional deterrent rather than some exotic factor in the leaf, because confined whiteflies oviposited more on the less-pubescent adaxial surface than on the abaxial surface, and because mortality rates on the two surfaces were similar (unpublished data).

Striking differences in whitefly adult and egg counts and the differential trichome configurations warrant further investigation. Mode of action of the apparent mortality on the adaxial leaf surface of PI 419090 and qualitative studies of the trichomes of PI 432342 should prove interesting and potentially useful.

\section{Literature Cited}

Butler, G.D., Jr., and T.J. Henneberry. 1984. Bemisia tabaci: Effect of cotton leaf pubescence on abundance. Southwest, Entomol. 9:91-94.

Butler, G.D., Jr., T.J. Henneberry, and T.E. Clayton. 1983. Bemisia tabaci (Homoptera: Aleyrodidae): Development, oviposition, and longevity in relation to temperature. Ann. Entomol. Soc. Amer. 76:310-313

Cohen, S., J.E. Duffus, and H.Y. Liu. 1992. A new Bemisia tabaci biotype in the southwestern 
United States and its role in silverleaf of squash and transmission of lettuce infectious yellows virus. Phytopathology 82:86-90.

Duffus, J.E., R.C. Larsen, and H.Y. Liu. 1986. Lettuce infectious yellows virus-A new type of whitefly-transmitted virus. Phytopathology 76:97-100.

Edelson, J.V. 1986. Comparison of sampling methods for insect pests of cantaloupe. J. Econ. Entomol. 79:266-270.

Flock, R.A. and D.E. Mayhew. 1981. Squash leaf curl, a new disease of cucurbits in California. Plant Dis. 65:75-76.

Gerling, D. 1967. Bionomics of the whitefly-parasite complex associated with cotton in southern California (Homoptera: Aleyrodidae; Hymen- optera: Aphelinidae). Ann. Entomol. Soc. Amer. 60:1306-1321.

Hayat, N.A. 1978. Introduction to biological scanning electron microscopy. Univ. Park Press, Baltimore.

Hoxie, R.P. and S.G. Wellso. 1975. Cereal leaf beetle response to wheat trichome length and density. Environ. Entomol. 4:365-370.

McCreight, J.D. and A.N. Kishaba. 1991. Reaction of cucurbit species to squash leaf curl virus and sweetpotato whitefly. J. Amer. Soc. Hort. Sci. 116:137-141.

Pcrring, T.M., A. Cooper, D.J. Kazmar, C. Shields, and J. Shields. 1992. New strain of sweetpotato whitefly invades California vegetables. Calif. Agr. 45(6):10-12.
Sippell, D.W., O.S. Bindra, and H. Khalifa. 1987. Resistance to whitefly (Bemisia tabaci) in cotton (Gossypium hirsutum) in the Sudan. Crop Protection 6(3):171-178.

Snedecor, G.W. 1956. Statistical methods. 5th ed. Iowa State College Press, Ames.

Turnipseed, S.G. 1977. Influence of trichome variations on populations of small phytophagous insects in soybean. Environ. Entomol. 6:815817.

Ward, G.M. 1973. Calcium deficiency symptoms in greenhouse cucumbers. Can. J. Plant Sci. 53:849-856.

Webster, J.A., D.H. Smith, E. Rathke, and C.E Cress. 1975. Resistance to cereal leaf beetle: Density and length of leaf-surface pubescence in four wheat lines. Crop Sci. 15:199-202. 